\title{
Southwest Airlines' successful economistic, cost-leadership strategy examined in light of Paul Lawrence's renewed Darwinian theory: An analysis
}

Nadya Chishty-Mujahid

The Institute of Business Administration

\section{Recommended Citation}

Chishty-Mujahid, N. (2017). Southwest Airlines' successful economistic, cost-leadership strategy examined in light of Paul Lawrence's renewed Darwinian theory: An analysis. International Interdisciplinary BusinessEconomics Advancement Journal, 2(2), 115-123.

\section{Revisions}

Submission date: Oct. 22, 2016

1st Revision: Mar. 3, 2017

2nd Revision: Apr. 24, 2017

3rd Revision: Jun. 10, 2017

Acceptance: Aug. 1, 2017 


\title{
Southwest Airlines' Successful Economistic, Cost-Leadership Strategy Examined in Light of Paul Lawrence's Renewed Darwinian Theory: An Analysis
}

\author{
Nadya Chishty-Mujahid
}

\author{
Social Sciences and Liberal Arts \\ The Institute of Business Administration, Pakistan \\ nchishty@iba.edu.pk
}

\begin{abstract}
This paper examines the successful business strategy employed by Southwest Airlines with special respect to the recent theories of Paul Lawrence. Long-time professor of organizational behavior at Harvard Business School, Lawrence posited that Renewed Darwinian theory reflected four basic human drives: acquisition, defense, comprehension, and bonding. Given Michael Porter's assessment of the distinctions between cost leadership and differentiation, my analysis reveals that Southwest succeeded in maintaining its competitive market niche for the air-travel industry by engaging in a strongly economistic, cost leadership strategy that primarily incorporated and prioritized aspects of the drives to acquire and defend. In doing so it displayed greater vision and operational effectiveness than its competitors (such as Continental Lite, for example).
\end{abstract}

Keywords: renewed Darwinian theory, airline management strategy, cost leadership

\section{Introduction}

The purpose of this specific paper on strategy and economic theory is to examine the recent academic theories of the late Harvard professor Paul Lawrence that were initially consolidated in his book, co-authored with Nitin Nohria, titled Driven: How Human Nature Shapes Our Choices (2002), and their specific validity when it comes to the case of Southwest Airlines. Given that Lawrence was a senior and respected professor of organizational behavior at Harvard, and Nohria is now Dean of the Harvard Business School, their findings merit special academic consideration especially when explored alongside the long-established and insightful theories of Michael Porter (also a Harvard University professor) concerning strategy, differentiation, and cost leadership. Shortly before he passed away, Lawrence also authored Driven to Lead: Good, Bad and Misguided Leadership (2010) in which he continued to build on the theories first put forward by him and Nohria in his earlier text. Lawrence was of the opinion that in addition to the two fundamental Darwinian drives - those concerned with acquisition and defense - two other drives (those that relate to comprehension and bonding) are necessary for success when it comes to business matters in general and corporate affairs in particular. However, my specific analysis of the case of Southwest Airlines both implicitly and explicitly indicates that only the two 
original Darwinian drives are predominantly vital to the smooth running of an organization that prioritizes cost leadership strategy.

In what some may regard as an exemplary exercise in interdisciplinary thinking, Lawrence read extensively on topics such as psychology, neuroscience, and social studies and combined his newly acquired knowledge with his sound expertise in Management Studies in order to construct an analytical model termed Renewed Darwinian theory. In a useful academic article titled 'Humanism in Business: Towards a Paradigm Shift?' Pirson and Lawrence (2010) postulate the following:

In essence RD [Renewed Darwinian] theory illuminates how the human brain has developed via natural selection and also through sex and group selection mechanisms to make complex decisions regarding all aspects of life (personal, communal, and societal). It posits four basic drives, ultimate motives that underlie all human decisions (p. 556).

The critics claim that two primal drives exist in all creatures that engage in some form of selfpreservation. These are the drive to acquire (dA) those resources that are fundamental to the sustenance of life, and the drive to defend (dD) oneself (successfully, and at times ruthlessly) from external threats. However, Pirson and Lawrence also posit that on a gradual basis humans specifically developed two newer drives, namely the drive to bond $(\mathrm{dB})$ and the drive to comprehend $(\mathrm{dC})$. The two latter drives are integral to the critics' central thesis: that human bonding and mental comprehension make for a better and more humanistic system of business governance and management. According to Lawrence economistic and profit-driven systems of business have relied too heavily in the past on simply focusing on the desire to acquire and defend power, money, and influence. This results in the creation of specific types of leaders whom he regards as being people without conscience. He and Pirson argue that future business models need to be more humanistic and hence less economistic in nature; moreover, they can do this by more actively exhibiting the drives to bond and comprehend. From the general perspective of Management Studies and the more particular vantage-point of theories involving strategy it is fruitful to examine what implications Lawrence's theories might have for cost leadership and differentiation strategy. Porter's views on strategy posit that firms can seek to engage in cost leadership behavior which combines low-cost strategy with a strong desire to acquire a competitive advantage in the market. Since cost leadership behavior is inherently economistic in nature it is also primarily utilitarian in scale and scope. Insofar as original Darwinian theory is concerned one may assume that cost leadership reflects a strong desire to acquire revenue and profits, and defend the firm's financial position competitively in relation to other firms. This is a traditional management-related view of competitive strategy that derives its legitimacy from a fundamentally market-based approach, and one that has been adhered to by Southwest Airlines since the organization's inception.

\section{Literature Review}

Since this article demonstrates a completely original topic, i.e. one that has not been academically examined before, the research material for this article falls into two main categories. The first of these relates to Lawrence's theories which have been propounded in two books of which the text Driven to Lead (2010) is the most recent. As noted in the above introduction Pirson and Lawrence (2010) have additionally examined the humanistic aspects of this theory. The second category involves studies such as an article by Morrison (2001) that 
dwell specifically on the history of Southwest Airlines and the various factors (most notably enhanced competition) that have contributed towards the airline's success as an established corporate organization. In her book-length study on Southwest titled The Southwest Airlines Way (2003) Brandeis University professor Gittell (2003) assesses that:

Although Southwest's growth seems rapid and sudden, in fact the company has grown at a nearly consistent annual rate of 10 to 15 percent over the 32 years of its existence as part of a very deliberate philosophy of controlled growth (p. 7).

This point is validated by recent and current SWOT analyses and market reports for Southwest Airlines carried out by Marketline (2016). The task of this article is to create a specific case study, not simply one that focuses on Southwest's general performance but rather one that addresses whether its strategies validate the Lawrence paradigm or not. Gittell further notes that in 1993, the U.S. Department of Transportation implicitly bestowed a distinction on Southwest by claiming that it was:

the dominant airline in the United States because of the effect it was beginning to have on the rest of the industry. They coined a new term-the "Southwest effect" - the change in fares and passenger volumes that is observed when Southwest enters a market. According to the report, when Southwest announces service on a new route, other airlines serving that route almost immediately reduce their fares, and sometimes increase their frequencies as well (Gittell, 2003, p. 7).

This strongly competitive aspect of Southwest has also been extensively examined by Morrison (2001). Regarding the (contrasting) differentiation model Jones and Butler (1988) note:

[A] successful differentiation strategy insulates a business from competitive rivalry and captures customers by creating customer loyalty and lowering customer sensitivity to price. ... On the other hand, cost leadership implies that the firm is attempting to capture customers primarily through price, and this is a more market-like governance mechanism (p. 204).

Certainly, insofar as competitive business is concerned there are advantages to both strategic models, but given Pirson and Lawrence's humanistic ideas one must carefully analyze whether those ideas are applicable and strongly relevant to Porter's (2011) schema of cost leadership and differentiation.

\section{Methodology}

As already indicated earlier while the methodology for this article falls under the general category of a case-study approach, the main point of the article is not just a simple case-based examination of Southwest's strategies but rather of viewing those strategies in light of the Lawrence paradigm in order to determine whether (and if so, why) the airline's strategy resonates most strongly with certain Darwinian drives as opposed to others. Marketline's (2016) relatively recent company profile of Southwest that engages in a full SWOT analysis of the airline claims that:

Robust operating strategy allows the company to achieve high asset utilization and reliable on-time performance, which in turn helps the company to increase its revenues and to tap profitable markets. However, intense competition could adversely impact the company's operating results, financial condition and liquidity (p. 4). 
An examination of one of Southwest's major competitors is therefore necessary in order to begin to underscore how Southwest utilizes the drives to acquire and defend over and above those that entail comprehension and bonding. The methodology below will focus on contrasting Southwest's performance with that of one of its main competitors (Continental Lite) and relating this contrast to Lawrence's Renewed Darwinian theories. This will lead towards an examination of how Southwest's strategic principles implicitly underscore its successful cost leadership strategies.

In order to achieve these specific aims one can examine the comparative cases of competing business strategies employed by Southwest Airlines and Continental Lite. Southwest commenced operations in the late 1960s and has survived for close to fifty years by adhering to a remarkably sound low-cost strategy that also works in tandem with the company's noted operational effectiveness. In his influential essay titled What is Strategy? leading business academician Porter (2011) claims that as opposed to full-service airlines Southwest by contrast strives for highly economical service that maximizes customer convenience:

Through fast turn-arounds at the gate of only 15 minutes, Southwest is able to keep planes flying longer hours than rivals and provide frequent departures with fewer aircraft. Southwest does not offer meals, assigned seats, interline baggage checking, or premium classes of service. Automated ticketing at the gate encourages customers to bypass travel agents, allowing Southwest to avoid their commissions. A standardized fleet of 737 aircraft boosts the efficiency of maintenance. Southwest has staked out a unique and valuable strategic position based on a tailored set of activities. On the routes served by Southwest, a full-service airline could never be as convenient or as low cost (p. 9).

It is evident from Porter's summary that Southwest operates, and has operated, from a distinctly cost leadership position, and indeed its customers are fully aware of the numerous benefits and advantages of the firm's consistent use of this type of strategy.

Southwest's customers' priorities may thus be considered to be aligned with those of the airline itself, where travelling between destinations quickly and cheaply takes precedence over and above perks such as airline meals. These cost-cutting measures on the part of Southwest ensure that its specific body of customers (i.e. those who wish primarily to travel at cheap rates) remain consistently satisfied. Naturally those individuals who require the added benefits of classes of service, etc. have to consider looking elsewhere for travel purposes. In aggregate, Southwest's success can be gauged by noting that over the years it has maintained its reputation for cost efficiency and currently rakes in a revenue of approximately 20 billion US dollars. It should also be underscored that in light of Paul Lawrence's Renewed Darwinian theory Southwest has displayed a greater implicit emphasis on the drives to acquire and defend as opposed to those related to bonding and comprehension. Some element of the drive to comprehend would definitely have been manifested in the creation of the original cost leadership vision of the airline; however, that comprehension of its ultimate goals would have necessarily fed into important acquisition of revenue and also into defending the market niche/position. In a study of Southwest's competitive position conducted in 1998, Morrison (2001) noted that estimated savings to air travelers:

due to competition from Southwest was $\$ 12.9$ billion. Southwest's low fares were directly responsible for $\$ 3.4$ billion of these savings to passengers. The remaining $\$ 9.5$ billion represents the effect that actual, adjacent, and potential competition from Southwest had on other carriers' fares. These savings amount to 
20 per cent of the airline industry's 1998 domestic scheduled passenger revenue and slightly more than half of the fare reductions attributed to airline deregulation - a sizable impact from a carrier that accounts for about 7 per cent of the industry's domestic scheduled passenger miles (p. 254).

Given these statistics it is safe to assume that no airline that did not prioritize acquisition and defense would have been able to achieve such staggering competitive aims.

It is therefore entirely understandable that competing airlines such as Continental would have wanted to duplicate Southwest's financial merits and general success. However, airlines that were operating using strategies of differentiation found that trying to duplicate Southwest's economistic strategy necessitated considerable trade-offs. In the early 1990s in order to become a viable competitor for Southwest's corner of the air-travel market Continental Airlines attempted to straddle between its present position and a newer, more cost-leadership oriented position. It created a subsidiary branch named Continental Lite that was aimed at serving customers the way that Southwest had been doing for the past thirty years. In describing how Continental Airlines decided to straddle between strategies and attempted to imitate some of Southwest's low-cost features by creating Continental Lite, Porter (2011) assesses that finally it was poor trade-offs that proved eminently detrimental, both at the financial and executive levels, to Continental Lite. Excessive delays and affiliated problems related to slow baggage transfers (which unfortunately prove fatal when it comes to the smooth running of most airlines) contributed to complaints against the airline that piled up at an alarming rate. Porter (2011) further summarizes that:

Continental Lite could not afford to compete on price and still pay standard travel-agent commissions but neither could it do without agents for its full-service business. The airline compromised by cutting commissions for all Continental flights across the board. Similarly, it could not afford to offer the same frequent-flier benefits to travelers paying the much lower ticket prices for Lite service. It compromised again by lowering the rewards of Continental's entire frequent-flier program (p. 19).

Unfortunately, within two years from its launch in 1993 Continental Lite folded completely, losing a couple of hundred million dollars and sustaining some damage to Continental's reputation. Obviously Continental Airline's management strategists and executives could not have predicted that their competitive brain-child would be such a colossal failure since no firm wishes to actively risk both its funds and image in this manner. What failed them during the planning stages of their venture was the drive to comprehend. Indeed, the reason Continental Lite went belly-up was because even its top management strategists did not fully comprehend or appreciate the impact that the abovementioned economic trade-offs would have on both operational effectiveness as well as (consequently) general revenue. However, it is important to point out at this juncture that the drive to comprehend serves the more major, overriding drives to acquire and defend since the latter are directly related to revenue generation and augmentation.

Regarding such substantial shifts in leadership and management strategies McGee, Dowling, and Megginson (1995) note that:

Both the transaction cost and strategic behavior approaches suggest the effects of cooperative behavior may be driven by the experience and capabilities possessed by the management team. For example transaction costs can conceivably be lowered if the management team writing and enforcing the cooperative contracts is more knowledgeable about competitive trends. ... Strategic behavior theory suggests that a management 
team will choose partners and types of cooperative activities in order to improve a firm's competitive position (p. 566).

The main problem vis-a-vis the scenario just delineated above had to do with inept planning and incomplete comprehension which led to Continental's inability to create and sustain a competitive position relative to Southwest, let alone maintain such a position on a long-term basis. The airline was unable to move from a more differentiated position to one of greater cost leadership because unless one can handle the substantial trade-offs involved one cannot smoothly and efficiently move along the strategy curve towards far lower costs and better revenue. It is not that Continental demonstrated any marked indifference towards their customers or an active failure to exhibit the drive to bond. Rather the problem was primarily not so much one related to a lack of bonding as much as a lack of comprehension. Moreover, since effective comprehension helps translate to success in competitive business, the failure of Continental's drive to comprehend had a direct impact on Continental Lite's ability to acquire and defend. Putting the matter in a nutshell, Southwest's competitor thought it could straddle strategies effectively when in point of fact it emphatically could not.

In addition to this, from a strategic point of view it is important to note that simple operational effectiveness would not have guaranteed Continental Lite's competitive advantage over Southwest. For many firms that have found themselves in a similar position Porter (2011) asserts:

\footnotetext{
The root of the problem is the failure to distinguish between operational effectiveness and strategy. The quest for productivity, quality, and speed has spawned a remarkable number of management tools and techniques: total quality management, benchmarking, time-based competition, outsourcing, partnering, reengineering, change management. Although the resulting operational improvements have often been dramatic, many companies have been frustrated by their inability to translate those gains into sustainable profitability (p. 2).
}

The reason that Southwest Airlines has sustained its profits and good reputation for close to five decades is because alongside operational effectiveness it has consistently sought to sustain its strategy of cost leadership. Moreover, it has always kept in mind the fact that there are considerable trade-offs associated with shifting or changing its position and has repeatedly demonstrated a skillful and wise use of the drive to comprehend when shaping its ongoing vision as regards acquisition of profits and defense of competitive position.

Porter is by no means the only academic to comment favorably on Southwest's management policies. Gadiesh and Gilbert (2011) opine that in the case of Southwest Airlines:

employees have consistently made trade-offs in keeping with the company's strategic principle. The process for making important and complicated decisions about things like network design, service offerings, route selection and pricing, cabin design, and ticketing procedures is straightforward. That is because the trade-offs required by the strategic principle are clear (pp. 201-202).

I have already dwelt at length above on the manner in which Continental failed to comprehend and manage the trade-offs that were necessary to compete successfully with Southwest. Not only are the trade-offs required by Southwest very clearly evident to its employees, so too is Southwest's main strategic principle: it prides itself on being the low-cost airline. Gadiesh and 
Gilbert (2011) further emphasize that while the mission of any organization is a vital part of its culture and aims, it is its fundamental strategic principle that drives its activities. In other words, the strategic principle is action-oriented as opposed to simply aspirational. They claim that a sound strategic principle (as opposed to a company's aspirational mission):

is also crucial when a company is experiencing rapid growth. During such times, it's increasingly the case that less-experienced managers are forced to make decisions about nettlesome issues for which there may be no precedent. A clear and precise strategic principle can help counteract this shortage of experience (Gadiesh \& Gilbert, 2011, p. 198).

Not only is Southwest's strategic principle crystal-clear, the company's aim of being the low-cost airline implicitly incorporates the two major drives identified by Darwin and necessarily underscored by Lawrence - those of (revenue) acquisition and defense of competitive position. Greene (2009) encapsulates the importance of precise strategy formation in the following quote: 'A mind that is easily overwhelmed by emotion, that is rooted in the past instead of the present, that cannot see the world with clarity and urgency, will create strategies that will always miss the mark' (Greene, 2009, p. 1). The sense of purpose with which Southwest Airlines employs its overarching cost leadership strategies rarely misses the mark. In spite of the fact that all four of the drives identified by Lawrence are incorporated into Southwest's strategic aims, the specific nature of those aims (especially cost leadership strategy) necessitate that the drives to acquire and defend remain paramount to the airline's agenda.

\section{Findings}

Therefore, we find that Southwest Airlines' success and longevity has resulted in part from its consistent maintenance of a low-cost, operationally effective position, as well as a finelydeveloped strategic understanding (comprehension) of what it needs to do in order to defend its niche in the air-travel market. Obviously, it also engages in some level of bonding with its customers since they have remained satisfied with the company's performance and activities over the years. However, in the case of Southwest specifically it should be noted that the respective drives to comprehend and bond definitively serve the greater, overarching drives to acquire and defend. Continental Lite failed because it was unable to replicate Southwest's primarily economistic (and originally Darwinian) strategy. Over the years, Southwest has emerged as an eminently stable organization, given that it aptly demonstrates and satisfies the Darwinian drive to defend. While Porter has written extensively about this and can accurately be regarded as a premier expert in strategic management, other noteworthy academics have also commented on the manner in which business strategies may be classified, and their opinions are worth mentioning here. For instance, Blumentritt and Danis (2006) underscore that Miles and Snow's typology claims the existence of:

\footnotetext{
three stable archetypal organizations - termed defenders, analyzers, and prospectors - each with its own distinctive strategy. Defenders pursue narrow market domains, rarely make adjustments in their technology, structure, or methods of operation and devote primary attention to improving efficiency. In contrast, prospectors almost continuously search for market opportunities, possess flexible technologies, and are creators of change (p. 277).
}

It is plausible to assume that Southwest Airlines would clearly fall into the first category - that of a defender. The fact that it almost exclusively uses 737 aircrafts, follows a strategic principle that advocates and adheres to low-costs, efficiently delivers what it promises to customers, actively 
attempts to maximize profits and acquire revenue, and displays a marked tendency to defend its niche in its market domain, makes it a prime example of an organization that highlights the importance of economistic behavior, and from the perspective of Lawrence's theories Southwest highlights the importance of the two major drives identified in original Darwinian theory.

\section{Conclusion}

In spite of his theories regarding what he perceives to be the ideal balancing of all four drives by corporate leaders Paul Lawrence himself notes that reality often contradicts aspects of even the finest theory. In Driven to Lead (2010) he writes almost sardonically:

We find it hard to imagine the CEO of a cigarette company sponsoring basic scientific research on the suspected health risk of his company's product, assuring himself of the dire results, immediately warning the public to stop smoking, stopping the promotion of smoking, and letting his company's sales drop (Lawrence, 2010, p. 169).

As a parallel corollary to this statement one can safely posit that no CEO of Southwest Airlines can afford to underestimate the importance of cost leadership strategy to both the day-to-day operations of the company as well as its general long-term vision, and hence is unlikely to drastically change his or her leadership approach to Southwest's general management. In concluding one therefore returns full circle to estimating how Southwest's success would fit in with humanistic practices underscored by Paul Lawrence-practices that according to him emphasize the drives to bond and comprehend at least as much as (if not more than) the drives to acquire and defend. In the case of Southwest Airline's strategic behavior at least (especially as I have delineated it in the methodology section of this paper) the absolutely blunt answer is that Southwest's success owes far more to economism and utilitarianism as opposed to humanism. This is not to say that Southwest is anti-humanistic; rather, its position as an archetypal defender that engages in cost leadership strategy prioritizes the drives for acquisition and defense over and above the more recent ones underscored by Lawrence. However, Lawrence's research certainly acts as a useful foil by means of which one can better understand the way in which some organizations have continued to thrive strategically over the years. Commenting on Paul Lawrence's book Driven to Lead, reviewer Hurst (2011) feels it incumbent upon him to reveal the pitfalls that may arise from prescribing too zealously to the critic's humanistic position:

Lawrence is a distinguished management academic, and his provocative book is highly critical of the economic frameworks that have dominated management thinking in recent times. But like many academics, he seems to assume that new ideas can be substituted for old without changing people's habits' (Hurst, 2011, para. 5).

Hurst's points are well-taken but a major management academic at the tail-end of an illustrious career (a category into which Lawrence can safely be placed) should be commended for taking a critical stance that can potentially lead to thought-provoking reassessments within the complex field of business management. Moreover, to be perfectly fair-minded one cannot avoid taking some risks when it comes to ongoing new research in business academe especially if one wishes to develop a better understanding (by default if no other means) of why certain tried and true management strategies have persisted, in spite of obstacles, over the course of decades. Thus obliquely, if not directly, Lawrence's interdisciplinary work enables us to better comprehend and appreciate the economistic success of an airline whose management strategy aptly illustrates the principle of survival of the fittest. 


\section{References}

Blumentritt, T., \& Danis, W. (2006). Business strategy types and innovative practices. Journal of Managerial Issues, $18(2), 274-291$

Gadiesh, O., \& Gilbert, J. L. (2011). Transforming corner-office strategy into frontline action. In HBR's 10 Must Reads on Strategy (pp. 191-208). Cambridge, MA: HBS.

Gittell, J. H. (2003). The Southwest airlines way. New York, NY: McGraw Hill.

Greene, R. (2009). The concise 33 strategies of war. London, UK: Penguin.

Hurst, D. (2011). 'Drive theory' of leadership. Retrieved from https://www.strategy-business.com/article/11114b.

Jones, G., \& Butler, J. (1988). Costs, revenue, and business-level strategy. The Academy of Management Review, 13(2), 202-213.

Lawrence, P.R., \& Nohria, N. (2002). Driven: How human nature shapes our choices. San Francisco, CA: JosseyBass.

Lawrence, P. R. (2010). Driven to lead: Good, bad, and misguided leadership. San Francisco, CA: Jossey-Bass.

Marketline. (2016). Southwest Airlines Co. [SWOT analysis]. Retrieved from https://studydaddy.com/attachment/54301/crkin4d4os.pdf, 1-11.

McGee, J. E., Dowling, M., \& Megginson, W. L. (1995). Cooperative strategy and new venture performance: The role of business strategy and management experience. Strategic Management Journal, 16(7), 565-580.

Morrison, S. A. (2001). Actual, adjacent, and potential competition: estimating the full effect of Southwest Airlines. Journal of Transport Economics and Policy, 35(2), 239-256.

Pirson, M., \& Lawrence, P. (2010). Humanism in business-Towards a paradigm shift? Journal of Business Ethics, 93(4), 553-565.

Porter, M. (2011). What is Strategy? In HBR's 10 Must Reads on Strategy (pp. 1-38). Cambridge, MA: HBS. 